\title{
The origin of spheroidal patterns of weathering in the Pados-Tundra mafic-ultramafic complex, Kola Peninsula, Russia
}

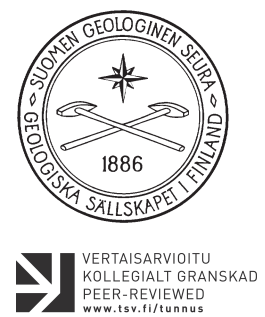
KOLLEGIALT GRANSKA
PEER-REVIEWED
www.tsv.fi/tunnus

\author{
Andrei Y. Barkov ${ }^{1 *}$, ANdrey A. Nikiforovi, \\ Tapio A. A. Halkoaho ${ }^{2}$ and Jukka P. Konnunaho 3 \\ ${ }^{1}$ Research Laboratory of Industrial and Ore Mineralogy, Cherepovets State University, \\ 5 Lunacharsky Avenue, 162600 Cherepovets, Russia \\ ${ }^{2}$ Geological Survey of Finland, P.O. Box 1237, 70211 Kuopio, Finland \\ ${ }^{3}$ Geological Survey of Finland, P.O. Box 77, 96101 Rovaniemi, Finland
}

We document a new and unusual occurrence of patterns of protruding spheroidal weathering developed in a dunitic rock of the Pados-Tundra mafic-ultramafic complex of Early Proterozoic age, Kola Peninsula, Russia. It provides an example similar to that reported recently from a mineralized harzburgite in the Monchepluton layered complex in the same region. These patterns are genetically different from common results of "normal spheroidal weathering" sensu stricto. The spheroidally weathered dunite at Pados-Tundra consists of a high-Fo olivine, OI $\left(\mathrm{Fo}_{87.5}\right)$, which is, in fact, not altered. Accessory grains of aluminous chromite are present. Relief spheroids (1.5 to $4 \mathrm{~cm}$ in diameter; up to $\sim 5 \mathrm{vol}$. \%) are distributed sparsely and heterogeneously. They are hosted by the olivine matrix and composed of talc, Tlc, and tremolite, Tr, (Mg\# = 95-96) formed presumably at the expense of orthopyroxene, Opx, (i.e., pre-existing oikocrysts) during a deuteric (autometasomatic) alteration. In contrast, oikocrystic Opx $\left(\mathrm{En}_{86.0}\right)$ is quite fresh in related spheroids at Monchepluton, in which only minor deuteric alteration $(\mathrm{Tlc}+\mathrm{Tr})$ are observed. We infer that (1) the ball-shaped morphology of the weathered surface is a reflection of the presence of oikocrysts of Opx, which crystallized after $\mathrm{Ol}$ at the magmatic stage; they were entirely replaced by the deuterically induced TIc $+\mathrm{Tr}$ at Pados-Tundra. (2) Differential rates of weathering are implied for rock-forming minerals in these ultramafic rocks, with a higher resistance of Opx vs. Fo-rich Ol, and $\mathrm{Tlc}+\mathrm{Tr}$ vs. Fo-rich Ol. (3) The ball-like shape of the large spheroids, produced by magmatic processes, may likely represent an additional factor of their higher stability to weathering in the superficial environment. Similar patterns can be expected in other mafic-ultramafic complexes, especially in layered intrusions.

Keywords: spheroidal weathering, chemical weathering, mafic-ultramafic rocks, PadosTundra complex, Kola Peninsula, Fennoscandian Shield, Russia.

*Corresponding author (e-mail: ore-minerals@mail.ru) 


\section{Introduction}

Spheroidal weathering, related to chemical weathering, is expressed by the appearance corestones, i.e., spheroids of relict bedrock of various compositions and sizes, which are mantled by concentric shells or rindlets arranged in zones (e.g., Chapman \& Greenfield, 1949; Ollier, 1971; Chatterjee \& Raymahashay, 1998; Fletcher et al., 2006).

In the present article, we document a new occurrence of unusual patterns of spheroidally weathered surface, which are, in fact, not related to processes of "normal" spheroidal weathering. These spheroids observed in a dunitic rock of the Pados-Tundra complex $(2.15 \mathrm{Ga})$ are similar to the patterns described recently, as a novel mechanism of spheroidal weathering, in a mineralized harzburgite of the Monchepluton layered complex $(2.5 \mathrm{Ga})$, also from the Kola Peninsula, Russia (Barkov et al., 2015). Here, we compare textures, compositions and mineral associations which are characteristic of these two occurrences and discuss factors responsible for the origin of the spheroid type patterns of weathering in ultramafic rocks.

\section{Geological background}

The Pados-Tundra complex is about $6 \mathrm{~km}$ long and $1.5-2.1 \mathrm{~km}$ thick (Figs. 1a-c). It is associated with an upthrust structure of Paleoproterozoic age, developed in the Lapland granulite rocks of the Kola-Mezenskiy block, near its contact with Archean granite and gneiss of the Belomorskiy block. This complex was considered to be a major representative of the Notozerskiy (Notozero) suite, known as a "Serpentinite belt" extending for over 40 km (Vinogradov, 1971; Zak, 1980). Results of radiometric dating gave a lower Proterozoic age of $2.15 \mathrm{Ga}$ for the Pados-Tundra complex (Shapkin et al., 2008; Shapkin \& Bayanova, 2009). Its geologic structure, investigated by Mamontov \& Dokuchaeva (2005), consists of meta gabbroic rocks of the "endocontact zone", and a rhythmically layered series of dunite - harzburgite - orthopyroxenite rocks (Fig. 1b). Dunite, a nearly monomineralic cumulate with 90-95 vol.\% olivine, contains minor orthopyroxene ( $<1$ vol.\%) and accessory grains of chromite-magnesiochromite (up to 2-3 vol.\%). Typically, harzburgite is composed of olivine $(60-70 \mathrm{vol} . \%)$ and orthopyroxene (up to $40 \mathrm{vol} . \%$ ), with minor chromite (up to 3 vol.\%). Orthopyroxenite is rich in a highly magnesian orthopyroxene: up to 95-97 vol.\%. Several layers of chromite and pipelike bodies rich in $\mathrm{Cr}$-Fe oxides occur in the Dunite block of the complex (Fig. 1b; Mamontov \& Dokuchaeva, 2005). In addition, there is a related body of dominantly ultramafic rocks in the vicinity of the Pados-Tundra intrusion; i.e., Malyi Pados ("Little Pados": Fig. 1c). Previous investigators (Mamontov \& Dokuchaeva, 2005, and references therein) interpreted it as being an individual or satellite intrusion. We suggest that, alternatively, it represents a block or fragment separated as a result of detachment from the Pados-Tundra complex.

\section{Protruding spheroidal weathering at Pados-Tundra}

The spheroidally weathered dunite occurs in outcrops in the northeastern part of the PadosTundra complex (Fig. 1b). Morphologically, the patterns observed (Figs. 2a, b) are notably similar to those developed at Mount Kumuzhya in the Monchepluton complex (Figs. 2c, d; Barkov et al., 2015). At Pados-Tundra, the relief spheroids (1.5 to $4 \mathrm{~cm}$ across) are sparsely developed and hosted by an olivine-based matrix. They are mostly composed of hydrous silicates, i.e. talc and tremolite, presumably deuteric (autometasomatic) in their origin, which have grown pseudomorphically at the expense of the oikocrystic orthopyroxene; grains of olivine and chromite are poikilitically enclosed within the former oikocrysts (Figs. 3a, b). Our observations imply that the oikocrystic grains of Opx generally extend in a layer-like manner at a level of close 


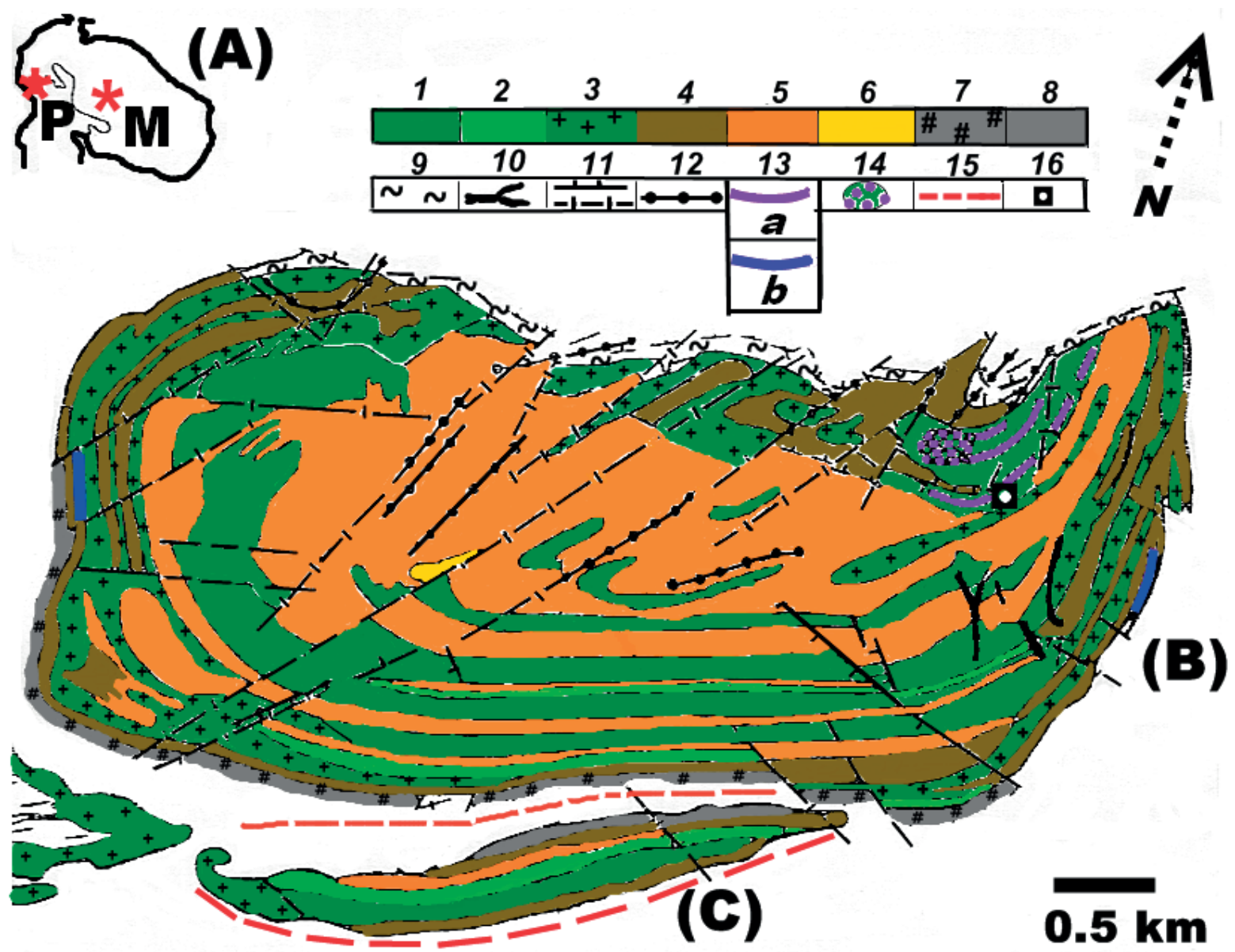

Figure 1 (a-c). 1a: the location of the Pados-Tundra (P) and Monchepluton (M) complexes in the Kola Peninsula, northwestern Russia; 1b: geological map of the Pados-Tundra complex (slightly modified from Mamontov \& Dokuchaeva, 2005). 1: dunite, 2: harzburgite, 3: serpentinite, 4: a tremolite-rich rock formed at the expense of orthopyroxenite, 5: orthopyroxenite, 6: olivine orthopyroxenite, 7: a chlorite-biotite-amphibole rock of the "exocontact zone", 8: gabbro, 9: mylonite or variously mylonitized rocks, 10: a talc-magnesite rock, 11: faults (observed: upper symbol or proposed: lower symbol), 12: dike of plagiogranite, 13: stratified layers of chromitite (13a), shown out of scale, and zones of Cr-rich magnetite (out of scale) at the contact (13b); 14: podiform and pipe-like orebodies rich in Cr-Fe oxides, 15: a fault zone proposed in this study, 16: location of the investigated outcrop with patterns of spheroidal weathering (this study). Fig. 1c shows the Malyi Pados intrusion, considered to be a satellite intrusive body (Mamontov \& Dokuchaeva, 2005). Alternatively, it represents a block detached from the Pados-Tundra complex, involving the proposed fault system (shown in red: this study). The scale bar is $0.5 \mathrm{~km}$.

to, and beneath of, the Lower (Main) layer of chromitite in the Dunite block.

Representative compositions acquired by wavelength-dispersive spectrometry (WDS; a Cameca SX100 electron-microprobe) are listed in Table 1. The WDS point-analyses gave narrow compositional ranges documented for 30 grains of olivine and chromite each, and 10 grains of talc and tremolite each, analyzed in their variously textured forms present in the spheroidally weathered dunite at Pados-Tundra. 

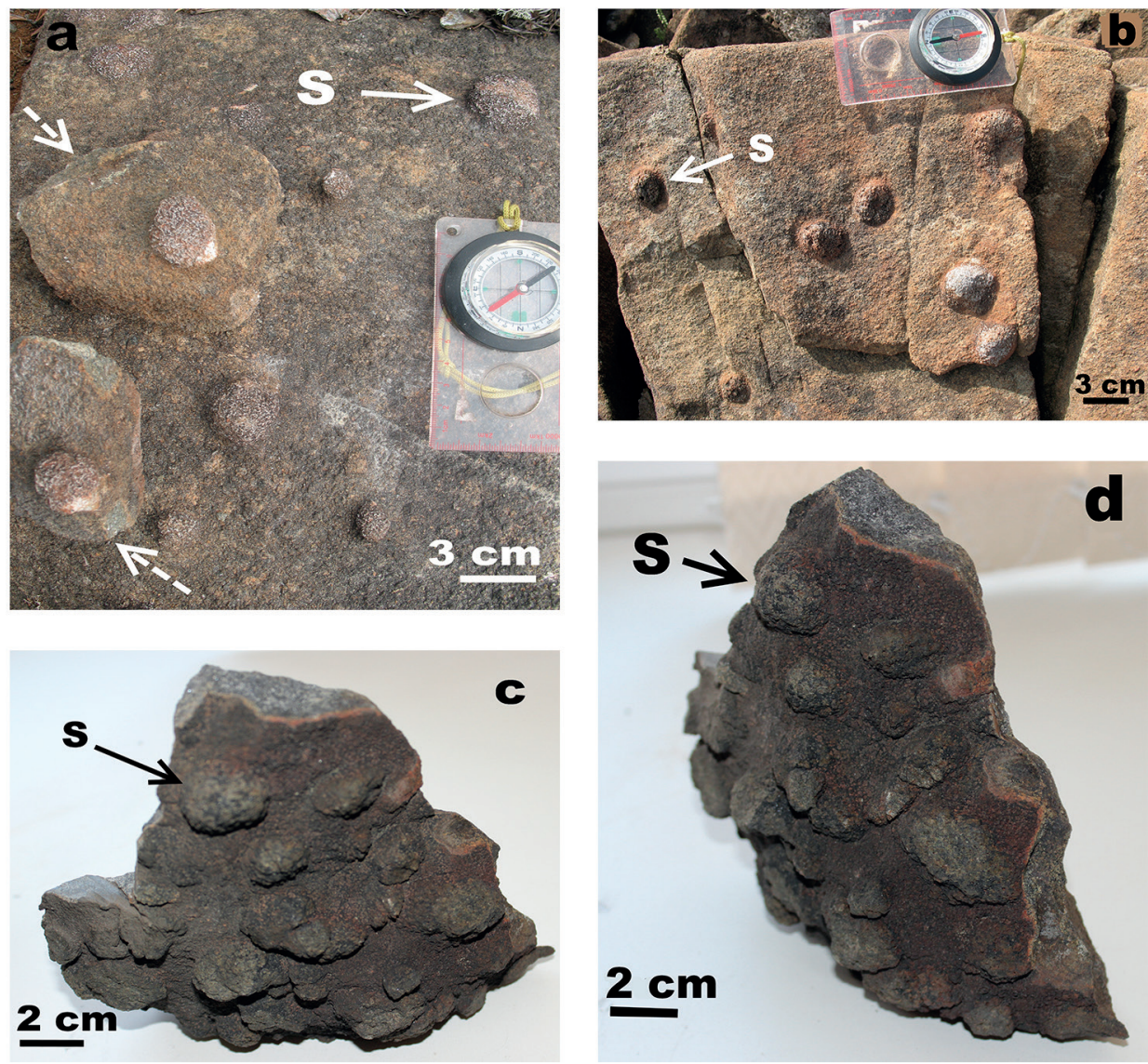

Figure 2 (a - d). Typical patterns of spheroidal weathering in ultramafic rocks of the Pados-Tundra (2a, b) and Monchepluton (2c, d; cf. Barkov et al., 2015) complexes. The observed spheroids (S), hosted by the olivine-rich matrix, are composed of orthopyroxene oikocrysts, which are entirely replaced by deuteric hydrous silicates (talc + tremolite) at Pados-Tundra. The dashed arrows point to specimens of spheroid type rocks collected from this outcrop. Note the development in the weathered crust (Fig. 2 c, d), and locally through the specimen, of a reddish material formed during weathering of grains of the Fo-rich olivine.

\section{Discussion}

\subsection{Comparison with Monchepluton}

The overall variations, observed at Pados-Tundra and Monchepluton, are compared in Table 2. At Monchepluton, the spheroids (Figs. 2c, d) are 3-4 $\mathrm{cm}$ oikocrysts of a highly magnesian orthopyroxene: $\mathrm{En}_{86}$, which enclose aggregates of chromitemagnesiochromite, and host inclusions of high-Fo olivine and magnesian augite (Barkov et al., 2015).
The documented spheroid type occurrences in the Kola Peninsula are notably similar. (1) They both are associated with oikocrysts or spheroids of orthopyroxene (entirely replaced or well preserved) associated with olivine cumulates in the matrix; (2) Grains of chromian spinel in these rocks (dunite vs. harzburgite: Table 2) are aluminous magnesian chromite; their compositions are notably similar, with a somewhat higher content of $\mathrm{Mg}$ (magnesiochromite component) and $\mathrm{Al}$, and correspondingly, lower $\mathrm{Fe}$ and $\mathrm{Cr}$ in the 
Table 1. Compositions of rock-forming and accessory minerals from dunite with patterns of spheroid type weathering, Pados-Tundra complex, Kola Peninsula

\begin{tabular}{|c|c|c|c|c|c|c|c|c|c|}
\hline No. & 1 & 2 & 3 & 4 & 5 & & 7 & 8 & 9 \\
\hline \multicolumn{10}{|l|}{ Weight \% } \\
\hline $\mathrm{SiO}_{2}$ & 40.21 & 62.58 & 62.96 & 57.68 & 57.82 & - & - & - & - \\
\hline $\mathrm{TiO}_{2}$ & - & 0.01 & 0.06 & 0.03 & 0.05 & 0.32 & 0.29 & 0.28 & 0.19 \\
\hline $\mathrm{Al}_{2} \mathrm{O}_{3}$ & - & 0.22 & 0.01 & 0.46 & 0.25 & 11.70 & 11.19 & 12.08 & 11.72 \\
\hline $\mathrm{Cr}_{2} \mathrm{O}_{3}$ & - & 0.06 & 0.06 & 0.21 & 0.17 & 49.25 & 51.58 & 50.33 & 50.88 \\
\hline $\mathrm{V}_{2} \mathrm{O}_{3}$ & - & - & - & - & - & 0.14 & 0.18 & 0.17 & 0.20 \\
\hline $\mathrm{FeO}$ (total) & 11.62 & 1.34 & 1.31 & 1.96 & 1.99 & 29.30 & 28.32 & 27.64 & 27.80 \\
\hline $\mathrm{FeO}(\mathrm{calc})$ & - & - & - & - & 1.85 & 25.39 & 25.57 & 25.28 & 25.11 \\
\hline $\mathrm{Fe}_{2} \mathrm{O}_{3}(\mathrm{calc})$ & - & - & - & - & 0.15 & 4.34 & 3.05 & 2.63 & 3.00 \\
\hline $\mathrm{MnO}$ & 0.18 & 0.01 & 0.01 & 0.11 & 0.07 & - & - & - & - \\
\hline MgO & 47.23 & 30.50 & 31.03 & 23.30 & 23.96 & 4.71 & 4.66 & 4.72 & 4.85 \\
\hline $\mathrm{CaO}$ & 0.01 & 0.01 & 0.02 & 12.50 & 12.38 & - & - & - & - \\
\hline $\mathrm{NiO}$ & 0.40 & 0.20 & 0.19 & 0.02 & 0.03 & 0.05 & - & 0.02 & 0.07 \\
\hline $\mathrm{ZnO}$ & - & 0.25 & 0.18 & - & 0.04 & 0.38 & 0.42 & 0.43 & 0.39 \\
\hline $\mathrm{Na}_{2} \mathrm{O}$ & - & - & - & 0.07 & - & - & - & - & - \\
\hline $\mathrm{K}_{2} \mathrm{O}$ & - & - & 0.01 & 0.04 & - & - & - & - & - \\
\hline Total & 99.65 & 95.18 & 95.84 & 96.38 & 96.77 & 96.28 & 96.94 & 95.94 & 96.41 \\
\hline \multicolumn{10}{|l|}{ Apfu } \\
\hline 0 & 4 & 11 & 11 & 23 & 23 & 32 & 32 & 32 & 32 \\
\hline $\mathrm{Si}$ & 1.00 & 3.99 & 3.99 & 7.97 & 7.96 & - & - & - & - \\
\hline $\mathrm{Al}$ & - & 0.02 & - & 0.08 & 0.04 & 3.90 & 3.71 & 4.03 & 3.90 \\
\hline $\mathrm{Cr}$ & - & - & - & 0.02 & 0.02 & 11.01 & 11.48 & 11.26 & 11.34 \\
\hline $\mathrm{V}$ & - & - & - & - & - & 0.03 & 0.04 & 0.04 & 0.05 \\
\hline $\mathrm{Ti}$ & - & - & - & $<0.01$ & $<0.01$ & 0.07 & 0.06 & 0.06 & 0.04 \\
\hline $\mathrm{Fe}^{2+}$ & 0.24 & 0.07 & 0.07 & 0.23 & 0.21 & 6.00 & 6.02 & 5.98 & 5.92 \\
\hline $\mathrm{Fe}^{3+}$ & - & - & - & - & 0.02 & 0.92 & 0.65 & 0.56 & 0.64 \\
\hline $\mathrm{Mn}$ & $<0.01$ & - & - & 0.01 & $<0.01$ & - & - & - & - \\
\hline $\mathrm{Mg}$ & 1.75 & 2.90 & 2.93 & 4.80 & 4.92 & 1.99 & 1.96 & 1.99 & - \\
\hline $\mathrm{Ca}$ & - & - & - & 1.85 & 1.83 & - & - & - & - \\
\hline $\mathrm{Na}$ & - & & - & 0.02 & - & - & - & - & - \\
\hline K & - & & - & $<0.01$ & - & - & - & - & - \\
\hline $\mathrm{Ni}$ & $<0.01$ & 0.01 & 0.01 & - & - & - & - & - & - \\
\hline $\mathrm{Zn}$ & - & & - & - & - & 0.08 & 0.09 & 0.09 & 0.08 \\
\hline Fo & 87.3 & & - & - & - & - & - & - & - \\
\hline $\mathrm{Fe} /(\mathrm{Fe}+\mathrm{Mg})$ & - & & - & - & - & 0.78 & 0.77 & 0.77 & 0.76 \\
\hline $\mathrm{Cr} /(\mathrm{Cr}+\mathrm{Al})$ & - & & - & - & - & 0.74 & 0.76 & 0.74 & 0.74 \\
\hline
\end{tabular}

Note. Ol is olivine (rich in forsterite, Fo); Tlc is talc; Am is amphibole (tremolite); and Chr is chromite. These results of WDS electron-microprobe analyses were acquired with a Cameca SX100 electron microprobe (at the Geological Survey of Finland, GTK, in Espoo) at $20 \mathrm{kV}$ and $60 \mathrm{nA}$ for olivine, and $15 \mathrm{kV}$ and 20nA for the other minerals listed. The beam size is 1 or $5 \mu \mathrm{m}$. FeO (total) is all Fe expressed as $\mathrm{FeO}$ (wt.\%). Contents of $\mathrm{F}$ and $\mathrm{Cl}$ in tremolite are lower than detection limits. Hyphen is "not detected" or "not applicable". Values of ferrous and ferric iron (calc.) were estimated on the basis of charge balance and stoichiometry. 

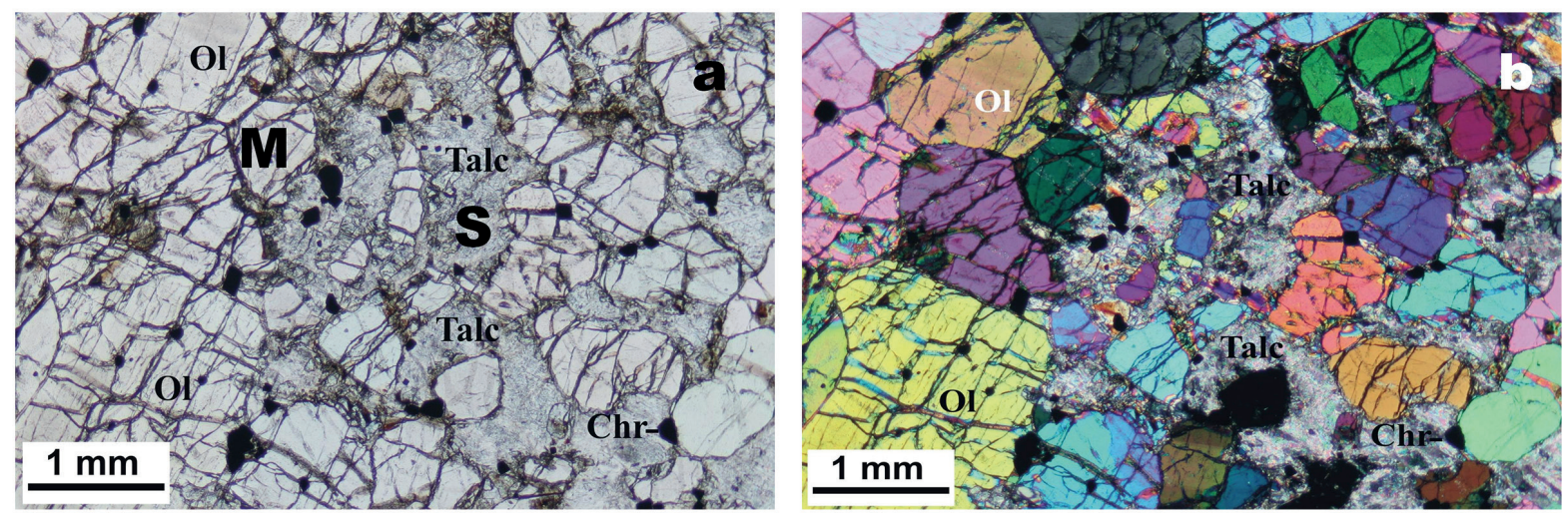

Figure 3 (a, b). Photomicrographs (a: transmitted light and 3b: cross-polarized light) showing the contact of the olivinerich matrix (M) with a spheroid (S), which consists of talc, formed presumably at the expense of pre-existing oikocryst of orthopyroxene, Pados-Tundra complex. Chr is chromite.

Table 2. Comparison of modal contents and compositions of minerals in ultramafic rocks with patterns of spheroid type weathering in the Pados-Tundra and Monchepluton complexes, Kola Peninsula

\begin{tabular}{|c|c|c|}
\hline & PADOS-TUNDRA(Dunite) & MONCHEPLUTON (Harzburgite) \\
\hline \multirow[t]{4}{*}{ MATRIX } & Olivine (>90 vol.\%) & Olivine ( 30 vol.\%) \\
\hline & $\mathrm{Fo}_{87.0-87.5}$ & $\mathrm{Fo}_{89.2-90.5}$ \\
\hline & $\mathrm{NiO}=0.36-0.41$ wt. $\%$ & $\mathrm{NIO}=0.4$ wt. $\%$ \\
\hline & $\mathrm{MnO}=0.17-0.19$ wt. $\%$ & $\mathrm{MnO}=0.15$ wt.\% \\
\hline \multirow[t]{3}{*}{ PHEROIDS } & Orthopyroxene: not preserved & Orthopyroxene ( 45-50 vol.\%) $\left[\mathrm{Wo}_{3.0} \mathrm{En}_{86.0} \mathrm{Fs}_{11.0}\right]$ \\
\hline & $\begin{array}{l}\text { Talc (deuteric after Opx) } \\
\text { Amphibole }\end{array}$ & Clinopyroxene $\left(<5\right.$ vol.\%) $\left[\mathrm{Wo}_{44.1} \mathrm{En}_{50.4} \mathrm{FS}_{5.5}\right]$ \\
\hline & (tremolite: Mg\# = 95.4-95.9) & Talc (deuteric after Opx) \\
\hline \multirow[t]{6}{*}{ CHROMITE } & Accessory grains & Segregations ( 20 vol.\%) \\
\hline & $\mathrm{Cr}_{2} \mathrm{O}_{3}=49.2-51.6 \mathrm{wt} . \%$ & $\mathrm{Cr}_{2} \mathrm{O}_{3}=46.5-49.3$ wt. $\%$ \\
\hline & $\mathrm{Al}_{2} \mathrm{O}_{3}=11.2-12.1 \mathrm{wt} . \%$ & $\mathrm{Al}_{2} \mathrm{O}_{3}=15.8-18.7$ wt. $\%$ \\
\hline & $\mathrm{MgO}=4.5-4.9$ wt. $\%$ & $\mathrm{MgO}=9.2-9.8$ wt. $\%$ \\
\hline & $\mathrm{Fe} /(\mathrm{Fe}+\mathrm{Mg})=0.8$ & $\mathrm{Fe} /(\mathrm{Fe}+\mathrm{Mg})=0.6$ \\
\hline & $\mathrm{Cr} /(\mathrm{Cr}+\mathrm{Al})=0.7-0.8$ & $\mathrm{Cr} /(\mathrm{Cr}+\mathrm{Al})=0.6-0.7$ \\
\hline
\end{tabular}

Note: Spheroidal patterns of weathering from the Pados-Tundra complex (this study) are compared with the patterns described from Mount Kumuzh'ya in the Monchepluton complex (Barkov et al., 2015). $\mathrm{mg} \#$ is $100 \mathrm{Mg} /\left(\mathrm{Mg}+\mathrm{Fe}^{2+}\right)$. 
harzburgite at Monchepluton. (3) Different amounts of deuteric talc and tremolite, replacing orthopyroxene, are uniformly present in these rocks. In contrast, the dunitic rock at Pados-Tundra has much lower amounts of pre-existing oikocrysts $(-5$ vol. $\%)$; it is poor in chromite and rich in olivine which is notably magnesian (ranges in Fo: 87.0-87.5 mol.\% vs. 89.2-90.5 mol.\%: Table 2). The relative enrichment in $\mathrm{Mg}$ (correspondingly, depletion in $\mathrm{Fe}$ ) in these grains of olivine at Monchepluton could be caused by their subsolidus re-equilibration or a high-temperature reaction with the associated chromite-magnesiochromite $(-20$ vol. \%). On the other hand, this chromite is richer in $\mathrm{Mg}$, consistent with a more magnesian depositional environment in the harzburgite unit at Mount Kumuzh'ya in the Monchepluton complex.

At Monchepluton, the following order of crystallization is indicated for the spheroidally weathered harzburgite (Figs. 2c-d): (1) crystals $\mathrm{Ol}(M:$ matrix $) \rightarrow(2)$ grains of chromite $(\mathrm{Chr})$, interstitial to $\mathrm{Ol}(M)$; subhedral grains of $\mathrm{Chr}$ hosted by Opx ( $S$ : spheroid) $\rightarrow$ (3) oikocrysts of Opx (S) crystallized from a more evolved (fractionated) melt; intercumulus clinopyroxene $\rightarrow$ (4) zoned $\mathrm{Chr}(M)$; and fluorapatite $(S)$ formed from droplets of trapped melts $\rightarrow$ (5) micrograins of nickel sulfides deposited at boundaries of Chr grains (S); inclusions of albite (in Chr) formed at $<400^{\circ} \mathrm{C}$ from trapped microdroplets of a highly evolved melt or from microbubbles of a residual melt enriched in $\mathrm{Na}$ and $\mathrm{Si}$, which are incompatible with $\mathrm{Chr}$ (Barkov et al., 2015).

The order of crystallization inferred for the Pados-Tundra specimen is generally consistent: (1) crystals $\mathrm{Ol}$ ( $M$ : matrix) $\rightarrow$ (2) grains of $\mathrm{Chr}$ [associated with $\mathrm{Ol}(M)$ and hosted by altered oikocrysts of Opx $(S)] \rightarrow(3)$ oikocrysts of Opx $(S)$ crystallized from a fractionated melt. (4) Finally, as a result of the enrichment and accumulation in an evolved melt of $\mathrm{H}_{2} \mathrm{O}$ and magmatic volatiles, the primary oikocrysts of Opx were entirely replaced by talc and tremolite during the autometasomatic stage of alteration (Figs. 3a, b).

\subsection{Factors favoring spheroidal weathering}

The formation of "normal patterns" of spheroidal weathering is generally based the following sequence of events: rectilinear systems of microfractures $\rightarrow$ rectangular blocks $\rightarrow$ rounding of their edges and angularities (Chapman \& Greenfield, 1949; Ollier, 1971; Chatterjee \& Raymahashay, 1998; Fletcher et al., 2006; Buss et al., 2008). No rindlets or pore spaces within a zone of rindlets, or a specific system of microfractures, are observed in our cases. Thus, the presently examined examples at Pados-Tundra are related to the spheroid type weathering documented at Mount Kumuzhya; indeed, these are distinct from the "normal spheroidal weathering". The following observations also are informative: (1) The harzburgite rock (Figs. 2c, d) is dense, unbroken and fresh. The grains exposed at the weathered crust surface show a strong internal integration with each other; therefore, such relief could not have formed by a physical selective disintegration of the olivine matrix. (2) The weathering front appears to be subsurface or surface-limited. Note that the weathered crust is rather thick, black with a reddish tint in the internally exposed layer (Figs. 2c, d); this material (probably a mixture $\mathrm{Fe}_{2} \mathrm{O}_{3}+\mathrm{FeOOH}$ ) is secondary, presumably rich in ferric iron and formed by oxidation of the released iron during the weathering of olivine grains.

The following characteristics are important to account for the development of spheroidal-type weathering at Monchepluton (Barkov et al., 2015): (1) The observed presence of large oikocrysts of orthopyroxene, which are a component of a magmatic texture. (2) The existing differences in rates of weathering of olivine and orthopyroxene. The Bowen's reaction series is consistent with an order of increasing stability of minerals at the Earth's surface: quartz is most stable and olivine is least stable. Besides, enstatite has a greater resistance than forsterite to a chemical weathering; the susceptibility series is: $\mathrm{Ol} \rightarrow \mathrm{Pl} \rightarrow \mathrm{Px} \rightarrow$ opaque 
minerals (Eggleton et al., 1987). The presently examined spheroids at Pados-Tundra, composed dominantly of hydrous silicates, indicate that talc and tremolite showed the greater resistance with respect to the associated olivine. In addition, individual specimens of spheroids identical to those present in situ (Figs. 2a, b) were found in a well-preserved state (commonly having ellipsoidal shapes), being fully liberated from the host olivine, in the ground near the examined outcrop.

\section{Concluding comments}

(1) A new occurrence of spheroidally weathered ultramafic rock is presently documented in a dunite of the Early Proterozoic Pados-Tundra complex. These forms are related to the spheroidal patterns described at Monchepluton, also from the Kola Peninsula (Barkov et al., 2015); they both clearly differ from the occurrences of "normal spheroidal weathering" sensu stricto. In contrast to "normal patterns" of spheroidal weathering, which are typically developed below the soil surface, the protruding ball-like forms of weathering occur on exposed surfaces of outcrops of the ultramafic rocks at Pados-Tundra and Monchepluton.

(2) As in specimens at Monchepluton, the ballshaped morphology of the weathered surface observed at Pados-Tundra is a reflection of the presence of large oikocrysts of orthopyroxene, which crystallized during a magmatic stage and were subsequently entirely replaced by autometasomatically produced talc and tremolite. The mixture of the latter minerals is quite soft. Therefore, processes of chemical weathering, rather than mechanical (physical) weathering, exerted a major control to form the relief surfaces of spheroid type in these ultramafic rocks.

(3) Presumably, the ball-like shape of the protruding spheroids could be an additional reason for their higher resistance to weathering and stability in the superficial environment.

(4) Similar patterns of spheroid-type weathering can well be expected in other mafic-ultramafic complexes, especially in layered intrusions.

\section{Acknowledgements}

We thank Drs. A. Hall (Stockholm University), R.F. Martin (McGill University), P. Sarala, Associate Editor, J. Heinonen, Editor-in-Chief, and an anonymous reviewer for helpful comments. We are grateful to M. Tiljander and L. Pakkanen at the Geological Survey of Finland (GTK) in Espoo, Finland, for the WDS EMP analyses. A.Y.B. thanks S. Kramzaev, a staff member at the Cherepovets State University, for his assistance during the field investigation of the Pados-Tundra complex in the years of 2015 and 2016 .

A.Y.B. gratefully acknowledges a partial support of this investigation by the Russian Foundation for Basic Research (project \# RFBR 16-05-00884). 


\section{References}

Barkov, A.Y., Nikiforov, A.A. \& Martin, R.F., 2015. A novel mechanism of spheroidal weathering: a case study from the Monchepluton layered complex, Kola Peninsula, Russia. Bulletin of the Geological Society of Finland 87, 79-85. https://doi.org/10.17741/bgsf/87.2.003

Buss, H.L., Sak, P.B., Webb, S.M. \& Brantley, S.L., 2008. Weathering of the Rio Blanco quartz diorite, Luquillo mountains, Puerto Rico: coupling oxidation, dissolution, and fracturing. Geochimica et Cosmochimica Acta 72, 4488-4507. https://doi.org/10.1016/j.gca.2008.06.020

Chapman, R.W. \& Greenfield, M.A., 1949. Spheroidal weathering of igneous rocks. American Journal of Science 247,407-429. https://doi.org/10.2475/ajs.247.6.407

Chatterjee, A. \& Raymahashay, B.C., 1998. Spheroidal weathering of Deccan Basalt: a three-mineral model. Quarterly Journal of Engineering Geology \& Hydrogeology 31, 175-179. https://doi.org/10.1144/gsl.qjeg.1998.031.P3.02

Eggleton, R.A., Foudoulis, C. \& Farkevisser, D., 1987. Weathering of basalt: changes in rock chemistry and mineralogy. Clays and Clay Minerals 35, 161-169. https://doi.org/10.1346/ccmn.1987.0350301

Fletcher, R.C., Buss, H.L. \& Brantley, S.L., 2006. A spheroidal weathering model coupling porewater chemistry to soil thicknesses during steady-state denudation. Earth and Planetary Science Letters 244, 444-457. https://doi.org/10.1016/j.epsl.2006.01.055
Mamontov, V.P. \& Dokuchaeva, V.S., 2005. The geology and ore potential of the Pados-Tundra massif in the Kola Peninsula. Otechestvennaya Geologiya 6, 52-60 [in Russian].

Ollier, C.D., 1971. Causes of spheroidal weathering. EarthScience Reviews 1, 127-141. https://doi.org/10.1016/0012-8252(71)90005-5

Shapkin, S. \& Bayanova, T., 2009. Geochronological Sm-Nd dating of the Cr-PGE-bearing Pados Massif (NorthWest Baltic Shield): new mineral and rock isochrones. In: Geophysical Research Abstracts 11, EGU2009-339-3, 2009.

Shapkin, S.S., Bayanova, T.B. \& Serov, P.A., 2008. PadosTundra - New Sm-Nd and U-Pb data for rocks of the massif (western part of the Kola Peninsula). In: Proceedings of the XIX Conference of young scientists in the memory of Prof. K.O. Kratz, November 24-28, 2008, Geological Institute, Kola Science Centre, Apatity [in Russian].

Vinogradov, L.A., 1971. The formation of Alpine-type ultrabasic rocks in the south-western part of the Kola Peninsula (The Notozersky ultrabasic belt). In: Problems of Magmatism of the Baltic Shield. Nauka [pp. 147-153; in Russian].

Zak, S.I., 1980. The Lower Proterozoic ultrabasic formations of the Kola Peninsula. Nauka [160 pp.; in Russian]. 